\title{
Policies for Implementing Internship Study 1 and 2 in Improving Student Achievement Index in FIP UNIMED
}

\author{
Yasaratodo Wau \\ Department of Administration of Education \\ Universitas Negeri Medan, Indonesia \\ yasaratodo@gmail.com
}

\author{
Rahmatsyah \\ Department of Physics \\ Universitas Negeri Medan, Indonesia \\ rahmat UNIMED@gmail.com
}

\author{
Tri Andri Hutapea \\ Department of Mathematics \\ Universitas Negeri Medan, Indonesia \\ triandrihutapea@gmail.com
}

\begin{abstract}
This study examines the problem on: (1) how's the impact of the policies on the implementation of Internship studies 1 and 2 programs in UNIMED (2) how to Increase the UNIMED Student's Learning Achievement Index. This study population consists all 2016/2017 academic year students who had conducted Internship Programs 1 and 2, with a sample of 142 people determined by random sampling techniques. The data of this study collected using a questionnaire instrument with a Likert Scale pattern. The results of data processing show that this research data contributes normally with a significant value of more than 0.05 at homogeneous variant level. The correlation coefficient obtained between the perceptions of students about the policy of implementing Internship study 1 and 2 program activities with the cumulative learning achievement index only reached 0.162 with the amount of contribution of 2.62 percent. The findings of this study indicate that the policy of implementing Internship study 1 and 2 program activities in UNIMED has less impact on the increase on student achievement indexes. Although it can be proven to correlate with learning commitment of 0.580 with a contribution of 33.64 percent, but the learning commitment does not necessarily affect the increase in the learning achievement index.
\end{abstract}

Keywords: policy, internship, learning achievement index, students

\section{INTRODUCTION}

In the 2016/2017 academic year, UNIMED has established and enacted new policies in the field of curriculum in the form of applying the Curriculum Model Based on Indonesian National Qualification Framework (KKNI). Based on this model, all academic activities refer to learning outcomes as internalization and accumulation of knowledge, skills, attitudes and competencies that can be achieved through structured education and training processes and covering certain fields of science or expertise.

In order to succeed the KKNI curriculum, UNIMED Leader has adopted a policy that required all 2016/2017 academic year students to take the Internship Course, with three stages namely: (1) Internship 1, namely the observation stage (observation) of learning practices in the classroom and management and the implementation of the school curriculum, in the second semester; (2) Internship 2, namely phase that examines the practical aspects of the school curriculum and its application in classrooms associated with UNIMED lectures, in the fourth semester; and (3) Internship 3, which is the Phase of drafting lesson plans and their implementation based on their links to lectures at UNIMED, in the sixth semester.

Through previous research studies, there was a sign that the Internship 1 course had a relationship with the commitment of students who's preparing to become Prospective Teachers and / or Education Personnel in FIP, especially in PLS FIP Study Program in UNIMED with a correlation coefficient of 0.49 and a contribution amount of 24.6 percent (Wau, 2017). The importance of learning experience from this internship program has also been investigated by several experts, including: (1) Ashland in collaboration with colleges and students (1996), (2) Deen Lango (2018), (3) Burns (2017), (4) Dove Terrence (2017), and (5) Lewis Anne C (2004) in equipping them with a number of learning experiences that are useful in shaping a variety of learning skills including development of learning commitment.

The extent to which the policies on the implementation of Internships 1 and 2 can determine or influence the achievement of the student achievement index needs to be studied scientifically through scientific research with the title: Policies for Implementing Internship Study 1 and 2 in Improving Student Achievement Index in FIP UNIMED.

\section{THEORETICAL STUDY}

Achievement index is one of the indicators of success in students learning activities. This achievement index shows the average value of all subjects that have been followed by students in a certain period of time. A particular semester performance index is called the semester.

Performance index, while the achievement index in some semesters is called the Cumulative Achievement Index. In a writings of a doctoral student on the page Commitment to Learn / My Ph.D Life, Chrisphdlife with the title of his note we need commitment more than 
motivation (https://chrisphdlife.wordpress.com/tag/ commitment-learning/) revealed that commitment comes from within ourselves about how much consistency we do what has been planned. Commitment is not based on feelings (like it or not, more enthusiasm, or not yes). Prayitno (2009) states that commitment is the willpower, determination, and determination to do better, to no longer repeat the wrong actions or violate them; will not do the same in the same place or elsewhere.

Likewise Luthans (2006) explains that organizational commitment can be defined as: (1) a strong desire to remain as a member of a particular organization, (2) a desire to strive according to organizational desires, and 3) certain beliefs, and acceptance of organizational values and goals, so can be synthesized that student learning commitment is as (1) a strong desire to remain as a student in a chosen department, (2) a desire to strive according to the desires of the study program, and 3) certain beliefs, and acceptance of the values and objectives of the department or study program. This learning commitment can be known quantitatively in the form of GPA/ or CGPA.

Based on a theoretical study it can be said that the achievement of GPA or CGPA is determined by various factors within or outside the self, including how to perceive the policies set by the Institute and its teaching staff in each course. Institutional policy in the form of determining various types and levels of lecture activities as outlined in the curriculum, syllabus, learning implementation plan that must be done by students, can determine learning commitments that will affect the level of achievement to be achieved by students.

The policy of applying Internship Courses can also be predicted to give opportunities for students to reflect on their learning activities. Students who have a true and correct understanding of the ins and outs of Internship course activities can be predicted to push themselves to have a high learning achievement index.

Based on the mindset above it can be synthesized that the policy of applying the Internship Course for students at UNIMED can encourage students to increase their learning achievement index at the tertiary level where they study, with the following research paradigms (Figure 1).

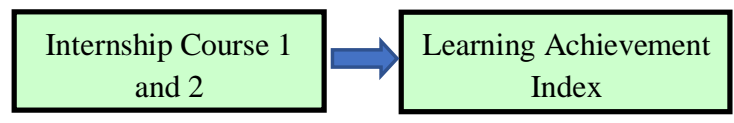

Figure 1

Contribution of Internship 1 and 2 Courses to Learning Achievement Index

Based on the theoretical framework and the framework of thinking above, the hypotheses proposed in this study are formulated as follows there is a meaningful contribution in Internship Courses 1 and 2 to the Student Learning Achievement Index at FIP UNIMED.

\section{METHOD}

The research was conducted at the Faculty of Education UNIMED for three to six months from June to November 2018. The study population included all UNIMED FIP students of the 2016/2017 Academic Year who had attended the Internship 1 and 2 Courses totaling 621 people, the sample consisted out of 141 people. The research method used is a quantitative method with questionnaire and documentation data collection techniques. Data is processed using correlational techniques with the Product Moment formula. The test was carried out at the significance level $(\alpha)=0.05$ (Sugiyono, 2014).

\section{RESULTS AND DISCUSSION}

The summary of research data is presented in Table 1 below. Based on the data in Table 1, calculation of the data tendency, normality and homogeneity tests are carried out, the correlation coefficient between the variables is shown in Table 2.

Table 1

Summary Description of Research Variables

\begin{tabular}{|c|c|c|c|}
\hline \multirow{2}{*}{$\begin{array}{l}\mathrm{N} \\
\mathrm{o}\end{array}$} & \multirow{2}{*}{$\begin{array}{l}\text { Descriptive } \\
\text { Analysis }\end{array}$} & \multicolumn{2}{|c|}{ Variabel } \\
\hline & & $\mathrm{X}$ & $\mathrm{Y}$ \\
\hline 1 & $\begin{array}{l}\text { Number of } \\
\text { Data }(N)\end{array}$ & 126 & 126 \\
\hline 2 & $\begin{array}{l}\text { Ideal } \\
\text { Maximum } \\
\text { Score }\end{array}$ & $180(5)$ & $135(5)$ \\
\hline 3 & $\begin{array}{l}\text { Ideal Minimum } \\
\text { Score }\end{array}$ & $108(2)$ & $81(2)$ \\
\hline 4 & Highest Scores & $180(5)$ & $130(4,8)$ \\
\hline 5 & Lowest score & $106(2,94)$ & $77(2,9)$ \\
\hline 6 & $\begin{array}{l}\text { Mean (Rata- } \\
\text { Rata) }\end{array}$ & $\begin{array}{l}148,48 \\
(4,12)\end{array}$ & $\begin{array}{l}112,94 \\
(4,18)\end{array}$ \\
\hline 7 & $\begin{array}{l}\text { Standard } \\
\text { Deviation }\end{array}$ & $15,54(0,42)$ & $10,45(0,38)$ \\
\hline 8 & Mode & $143(3,97)$ & $124(4,4)$ \\
\hline 9 & Median & $147,5(4,11)$ & $114(4,2)$ \\
\hline
\end{tabular}

Table 2

Frequency Data Distribution of Internship Subjects 1 and 2

\begin{tabular}{|c|c|c|}
\hline No & $\begin{array}{c}\text { Average } \\
\text { Interval Score }\end{array}$ & Frequency \\
\hline 1 & $2,7-3,0$ & 1 \\
\hline 2 & $3,1-3,4$ & 3 \\
\hline 3 & $3,5-3,8$ & 33 \\
\hline 4 & $3,9-4,2$ & 41 \\
\hline 5 & $4,3-4,6$ & 36 \\
\hline 6 & $4,7-5,0$ & 12 \\
\hline \multicolumn{2}{|c|}{} \\
\hline
\end{tabular}

Based on the data in Table 2, it can be described the level of data variability of students' perceptions of the Internship 1 and 2 Courses as follows (Figure 2).

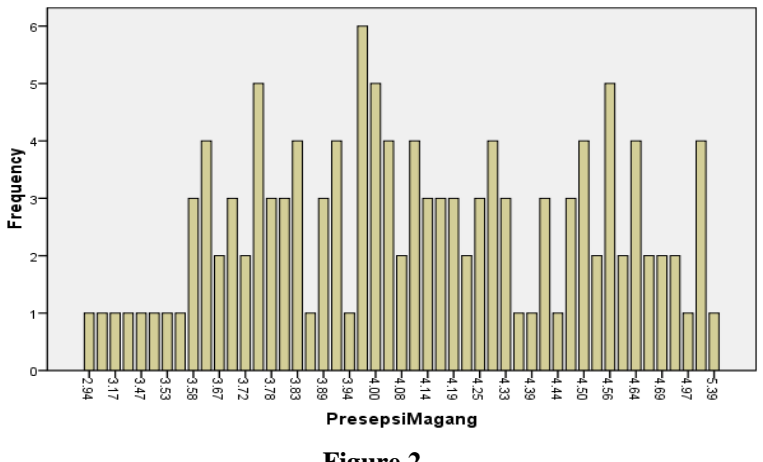

Bar Diagram of Student Data on Perception of Internships 1 and 2 in FIP UNIMED

Based on the data in Figure 2 it can be found that the data variable of Student Perceptions of Internship 1 and 2 
tend to be normal with an average score of 4.12 classified as high category. The correlation value between the internship perception variables and learning commitment to the Cumulative Grade Point Average is 0.162 (Table 3). This value is interpreted that to improve the cumulative achievement index is not enough with students having the internship perception and good learning commitment.

Table 3

Linear Regression of Internship Perception to Cumulative Achievement Index Variables Entered/Removed

\begin{tabular}{|c|l|c|c|}
\hline Model & \multicolumn{1}{|c|}{ Variables Entered } & $\begin{array}{c}\text { Variables } \\
\text { Removed }\end{array}$ & Method \\
\hline 1 & $\begin{array}{l}\text { Internship Perception, } \\
\text { Learning Commitment }\end{array}$ & $\cdot$ & Enter \\
\hline
\end{tabular}

Model Summary

\begin{tabular}{|c|c|c|l|c|}
\hline Model & R & R Square & $\begin{array}{l}\text { Adjusted } \\
\text { R Square }\end{array}$ & $\begin{array}{l}\text { Std. Error of } \\
\text { the Estimate }\end{array}$ \\
\hline 1 & .162 & .026 & .010 & .20767 \\
\hline
\end{tabular}

ANOVA

\begin{tabular}{|c|l|l|l|l|l|}
\hline Model & $\begin{array}{l}\text { Sum of } \\
\text { Squares }\end{array}$ & df & $\begin{array}{l}\text { Mean } \\
\text { Square }\end{array}$ & F & Sig. \\
\hline Regression & .143 & 2 & .072 & 1.662 & $.194^{\mathrm{a}}$ \\
1 Residual & 5.305 & 123 & .043 & & \\
Total & 5.448 & 125 & & & \\
\hline
\end{tabular}

\begin{tabular}{|c|c|c|c|c|c|}
\hline \multicolumn{6}{|c|}{ Coefficients } \\
\hline \multirow{2}{*}{ Model } & \multicolumn{2}{|c|}{$\begin{array}{l}\text { Unstandardized } \\
\text { Coefficients }\end{array}$} & \multirow{2}{*}{$\begin{array}{c}\begin{array}{c}\text { Stand } \\
\text { ardize } \\
\mathrm{d} \\
\text { Coeffi } \\
\text { cients }\end{array} \\
\text { Beta }\end{array}$} & \multirow{2}{*}{ 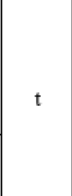 } & \multirow{2}{*}{ Sig. } \\
\hline & B & $\begin{array}{c}\text { Std. } \\
\text { Error }\end{array}$ & & & \\
\hline (Constant) & 3.301 & .217 & & 15.185 & .000 \\
\hline $\begin{array}{l}\text { Komitmen } \\
1 \text { Belajar }\end{array}$ & .104 & .060 & .189 & 1.728 & .086 \\
\hline $\begin{array}{l}\text { Presepsi } \\
\text { Magang }\end{array}$ & .078 & .053 & -.161 & -1.474 & .143 \\
\hline
\end{tabular}

Equation $\mathrm{Y}=3,301+0,104 \mathrm{X} 1-0,078 \mathrm{X} 2$, can be interpreted that if there is no internship perception value and learning commitment, the cumulative achievement index value is 3,301. Coefficient X1 at 0,104 dan X2 at 0,078 means that every 1 addition of the cumulative achievement index value, the value of internship perception increases by 0.104 and learning commitment by 0.078 .

Based on the calculation results of the regression equation and the correlation coefficient which is significant at the $5 \%$ level, the results of the study conclude that the research hypothesis stating there is a meaningful contribution to the Internship 1 and 2 Courses on Student Commitment to Learning in FIP UNIMED, is acceptable.

The results of the study above show that the policy of applying the Internship Courses which is predicted to increase the learning achievement index was not yet effective, although it means that perceptions of internships 1 and 2 contributed to student learning commitments by 33.64 percent with a correlation coefficient of 0.580 .

\section{CONCLUSIONS}

Contribution of the implementation of Internships 1 and 2 in UNIMED FIP on UNIMED Academic Year 2016/2017 FIP Student Achievement Index is relatively low: (a) to Semester Achievement Index of 0.013, and (b) to the Cumulative Achievement Index of 0.162. This means that UNIMED's policy of organizing Internships 1 and 2 for students is classified as less effective in terms of increasing the student's learning achievement index at UNIMED FIP. Therefore, it is hoped that all elements of LPTK leaders, especially at UNIMED, continue to design policies that are more challenging so that the holding of an Internship Course can help students improve their learning achievement to the fullest.

\section{REFERENCES}

[1] Ashland, 1996. Ashaland Bekerja dengan Universitas, Mahasiswa. Jurnal Teknologi Manajemen \&Teknik Terapan, Jan 20117.Vol 33. ISSN 2166-0123. ISSN 03638999.

[2] Burns. 2017, Meta Analisis Pengaruh Keterlibatan Industri pada Pembelajaran Siswa dalam Program Sarjana. Jurnal Teknologi Manajemen dan Teknologi Terapan.

[3] Deen Lango. 2018, Membangun Langkah Karir oleh Langkah. Jurnal EBSCO 2018, Insnyur Hispanik \& Teknologi Informasi Fall 2014.

[4] Dove Terrence,. 2017, Internship: 7 Hal yang Anda Butuhkan untuk Diketahui. Jurnal US Black Engineer dan Teknologi Terapan Vol.41.

[5] Echols, John M., 2003. Kamus Inggris Indonesia. Jakarta: Gramedia.

[6] Lewis Anne C., 2004. Tahun Kesuksesan. Journal Arah Tek. Vol 63

[7] Luthans, Fred, 2006. Perilaku Organisasi; Edisi Kesepuluh; Penerjemah: Vivin Andhika Yuwono, dkk.

[8] Mowday, $1982 . \quad$ http://jurnal-sdm. blogspot.com/2009/07/komitmen-karyawan-definisi-danjenis.html.

[9] Prayitno, 2009. Dasar Teori dan Praksis Pendidikan. Jakarta: Gramedia

[10] Peraturan Menteri Tenaga Kerja dan Transmigrasi No. Per.22/Men/IX/2009 tentang Penyelenggaraan Pemagangan di Dalam Negeri

[11] Rakhmat, Jalaluddin, 2005. Psikologi Komunikasi. Edisi Revisi. Bandung: Remaja Rosdakarya,

[12] Robbins, Stephen P., 2006. Perilaku Organisasi. Edisi Kesepuluh. Alih Bahasa Drs. Benyamin Molan. Jakarta: kelompok Gramedia

[13] Sugiyono. 2014. Statistik Untuk Penelitian. Bandung: Alfabeta.

[14] UNIMED, 2017. Pedoman Pelaksanaan Magang di UNIMED. Medan: UNIMED

[15] Wau, Yasaratodo, Anifah, Fauzi Kurniawan, 2017. Persepsi Tentang Hasil Refleksi Penyelenggaraan Kegiatan Magang 1 dan Hubungannya dengan Komitmen Mahasiswa Membekali Diri Menjadi Calon Tenaga Pendidikan di Program Studi Pendidikan Luar Sekolah FIP UNIMED

[16] http://id.shvoong.com/socialsciences/psychology/1837978-definisi-persepsi

[17] https://chrisphdlife.wordpress.com/tag/komitmen-belajar/. 